\title{
BAROKIZACIJA UMETNOSTI KOD SRBA I HRVATA DO 1760. GODINE SLIČNOSTI I RAZLIKE
}

\section{Ljiljana Stošić}

\author{
UDK: $7.034 .7(=163.41)^{“} 17^{“}$ \\ 7.034.7(=163.42)“17“
}

\begin{abstract}
Apstrakt: Heterogenost i eklektičnost umetnosti i umetnika kod Srba i Hrvata u prvoj polovini 18. veka značajnije ne odstupa od sličnih odlika srednjoevropskih stilova ovog razdoblja - baroka i rokokoa. Sveprisutna afektiranost i prenaglašena retoričnost ispoljavaju se kroz telesnu izvijenost, živu gestikulaciju i patetični izraz lica kao odraze preporučenih, katkad i štampanih slikovnih uputstava za dosezanje uverljivosti crkvene propovedi. Njihov krajnji cilj bilo je peobražujuće izmamljivanje suza i plača kod vernika. U srpskoj umetnosti uveliko zavisnoj od zapadnoevropskih bakroreznih predložaka, prvo će u grafici i arhitekturi, a potom u monumentalnom (freske), portativnom (ikone) i minijaturnom slikarstvu (iluminacije), kao i primenjenoj umetnosti, doći do barokizacije, evropeizacije ili modernizacije, za razliku od hrvatske umetnosti gde se ovaj proces odvijao istovremeno. Glavna karakteristika umetnosti kod Srba i Hrvata sredinom XVIII veka jeste preplitanje slike i reči u tolikoj meri da govor postaje slikovit a slika počinje da govori. Terezijanske i jozefinističke reforme postepeno će otupljivati oštrice militantne rimokatoličke crkve, utirući put verskoj toleranciji i umetnosti lišenoj konfesionalnog identiteta. Uočavanjem razlika u umetnosti susednih naroda često se ispuštaju iz vida suštinske prerušene sličnosti stvarane u nameri da samo izgledaju drugačije. Ovde se ukazuje na neke od njih.
\end{abstract}

Ključne reči: amblematika, barok, grafički predložak, Habzburška Monarhija, modernizacija, srpska i hrvatska umetnost, zapadnoevropske ilustrovane Biblije

zmeđu pojmova barokizacije, evropeizacije i modernizacije ${ }^{1}$ koje su obeležile umetnost 18. veka na područjima Austrije i južne Ugarske - gotovo da se može staviti znak jednakosti. Pod ovim odrednicama se poslednjih nekoliko vekova, a posebno decenija, podrazumeva ono što u manje razvijenim (istočno)evropskim zemljama poprima izgled i svojstva razvijenog zapadnoevropskog društva. Osim u privredi, politici, državnoj upravi, nauci i obrazovanju, ovi pojmovi se naročito često primenjuju u oblasti kulture i svim granama umetnosti. Za razliku od tradicionalističkih oblika neodvojivih od sujeverja, religioznosti i elitizma, osobenosti barokizacije, evropeizacije ili modernizacije počivaju na njihovim

\footnotetext{
Миодраг КОААРИЋ, „Модернизација српског сликарства у раздобьу зографа и молера”, Зборник Матище српске, 1954, бр. 8, 87; Аејан МЕААКОВИТ, Српска уметност у ХVIII веку, БеограА 1980, 11; Аепосва ШЕ МИЋ, „Западноевропски барок и српско зиАно сликарство 18. века”, Западноевропски барок и византијски свет. Зборникрадова (ур. Аејан Медаковић), БеограА 1991, 191.
} 
suprotnostima oličenim u scijentizmu, sekularizmu i masovnosti. ${ }^{2}$ Njihova rana faza, međutim, ne može se zamisliti bez međusobnog sadejstva suprotnosti u paralelnim tokovima staroga i novoga.

Jedan od vidova industrijske standardizacije unutar kulture i umetnosti jeste štampanje popularnih gravira namenjenih masovnoj potrošnji i podilaženju ukusu široke publike. ${ }^{3} \mathrm{U}$ svetu štampanih knjiga i umnožavanja jeftinih grafičkih ilustrovanih listova kao odocnelih vidova drvoreznih biblia pauperum, posebno mesto zauzima amblematska literatura. Njen osnovni cilj je bio da u svoje teško odgonetanje i razumevanje uključe celog - baroknog, evropskog ili modernog čoveka - zajedno sa njegovim stremljenjenjima ka multidimenzionalnom i interdisiplinarnom svetu (danas total look ili total image, u baroku Gesamtkunstwerk $)^{4}$ kao duhu vremena ${ }^{5}$ (Zeitgeist) jedne, u suštini, potpuno ideologizovane epohe prosvećenosti. ${ }^{6}$ Proces modernizacije umetnosti čiji naručioci i konzumenti, uz vladare i visoku crkvenu jerarhiju, ubrzano postaju obogaćeni pripadnici srednjeg staleža, zahvata prvo spoljne i popularne oblike umetničke pojavnosti kao što su arhitektura i grafika, ${ }^{7}$ a potom i njene unutarnje dekorativne vidove kakvo je slikarstvo, od monumentalnog (zidnog) preko portativnog (ikone) do minijaturnog (iluminacije), uključujući i predmete sa upotrebnom vrednošću, prvenstveno crkveni nameštaj i liturgijske sasudi ali i svetovne utenzilije.

Carica Marija Terezija se u gradnji palata, u opštim crtama, držala vladajućeg francuskog ukusa i stila Luja XIV. Ipak, bečki dvor u luksuzu i raskoši nije sledio lakomislena preterivanja Versaja, što znači da nije stalno naručivao i podizao nove palate, nego je stara zdanja preuređivao i preinačavao, proširivao i modernizovao, ${ }^{8}$ za šta su najbolji primeri bečki dvorci Hofburg, Šenbrun i Belvedere. Svi oni se zasnivaju na jednom, u osnovi, preuranjenom klasicističkom stilu sa barokno-rokajnom dekoracijom i mnoštvom egzotičnih elemenata preuzetih sa bliskog i srednjeg Istoka.

Tokom 17. stoleća barokizacija sakralnih objekata zahvata teritorije Austrije, Ugarske, Moldavije, Rusije i Ukrajine. Novi proces evropeizacije na teritorijama koje naseljavaju Srbi i Hrvati u okviru Habzburške Monarhije svoju ekspanziju doživljava u prvoj polovini 18. veka, a zajedničke su im nove graditeljske koncepcije podjednako vidljive u pregradnjama i dogradnjama starih, ${ }^{9}$ uglavnom drvenih hramova, i u njihovoj ponovnoj izgradnji u tvrdom i trajnom materijalu.

Osnove i preseci crkvenih objekata katoličkih bratovština koje se preuređuju u duhu novog vremena i stila, samo se formalno ali ne i suštinski razlikuju od svojih pravoslavnih parnjaka. Svi sakralni objekti, ma kojoj hrišćanskoj veri i crkvenom redu pripadali, imaju opšte imenitelje: proširivanje ulaznih i prozorskih otvora radi izrazite potrebe za svetlom, krečenje i prebeljivanje crkvenih zidova, povećanje unutrašnje korisne površine hrama, dograđivanje jedne ili više pobočnih kapela ili paraklisa, priziđivanje predvorja ili egzonarteksa u obliku otvorenog trema sa lukovima i stubovima nosačima, prigrađivanje ili zamena zvonika koji se izravnjavaju sa crkvenim pročeljem, izgradnja horova ili galerija

\footnotetext{
Slobodan ANTONIĆ, „Modernizacija”, Kritički pojmovnik civilnog društva (I), Beograd 2003, 233-234.

Vidi і Арием АЈУРАНТ, Аоба Волтера. Историја чивилизачије Западне Европе од 1715. до 1750, са посебним нагласком на сукоб између религије и филозофије, БеограА 2004, 311-313, 675-680.

Бранка КУАИЋ, Новосадске дрворезбарске радиониче у 18. веку, Нови СаА 2007, 39.

Александар КААИЈЕВИТ, Архитектура и дух времена, Београд 2010, 59-67.

Бранка КУАИЋ, нав. дело, 41.

Мирјана А. СТЕФАНОВИЋ, „Барок”, Аексикон српског просветитељства, БеограА 2009, 36-43.

Elfriede IBY, María Teresa (1717-1780). Biografía de una soberana, Wien 2010, 71.

John BOURKE, Baroque Churches of Central Europe, London 1978, 147-162.
} 
iznad ulaza u hram, kao i izmena spoljašnjeg izgleda crkava pomoću kulisnih završnica u obliku dozidanih zabata. ${ }^{10}$ Pri proširenjima i dogradnjama od posebne je važnosti podređivanje građevinskih aneksa glavnoj manastirskoj ili parohijskoj crkvi kao neprikosnovenoj arhitektonskoj dominanti, tako da sa njom čine skladnu i jedinstvenu prostornu i funkcionalnu celinu. ${ }^{11}$

U doba baroka, zapadnoevropske ilustrovane Biblije i pojedinačni grafički listovi iz 16. i 17. stoleća dospevaju kao slikarski predlošci i do naših krajeva. U srpskoj ${ }^{12}$ i hrvatskoj istoriografiji već je utvrđeno da su nizozemske i nemačke Biblije korišćene kao neposredni uzori u likovnoj ${ }^{13}$ i primenjenoj umetnosti. ${ }^{14} \mathrm{Za}$ razliku od hrvatske, ukrajinske i ruske umetnosti koje ove predloške koriste od sredine 17. stoleća, kod Srba proces barokizacije otpočinje u prvoj polovini 18. veka, pošto su se njihove grafičke prerade već potvrdile kao pravoverne u pravoslavnim sredinama kao što su Kijev i Moskva. Opraštanje od postvizantijskog kulturnog kruga kao zone branjene tradicionalne umetnosti, zapaža se u srpskoj umetnosti severno od Save i Dunava kroz raskidanje sa patrijarhalnom balkanskom sredinom i prilagođavanje novonastalim prilikama u Habzburškoj Monarhiji posle dve Velike seobe (1690/1739). Ilustrativni primeri su Biblije Nicolasa Joannisa Visschera zvanog Piscator (Amsterdam 1574), Cristopha Weigela, Johanna Ulricha Kraussa, Philipa Andreasa Kiliana i Caspara Lykena (Augsburg/Nirnberg, $17-18$. vek). ${ }^{15}$ Dok je kod Srba nizozemski zbornik Piskatorovih gravira iz Starog i Novog zaveta jedan od najranijih korišćenih - već od tridesetih godina 18. veka mada nikad u doslovnom vidu - na području Karlovačke mitropolije sredinom stoleća ga odmenjuje najpopularnija ilustrovana Biblija Ectypa augzburškog gravera i izdavača Christopha Weigela. Kod Hrvata se Piscator koristi mnogo duže i doslovnije, a gravire bakrorezaca okupljenih oko ovog izdavača primećene su kao grafički predlošci i u kontinentalnom i u primorskom delu Hrvatske. Mada su amsterdamska izdanja Bibilije koristili svi, među prvima Rusi i Ukrajinci koji ih svojim zidnim slikarijama umetnički nadilaze, nemačka Biblija Ectypa kod Srba postaje ono što je nizozemska Piscatorova Biblija bila kod Hrvata.

Recepciju zapadnoevropskih slikarskih predložaka u srpskoj umetnosti odlikuje međusobno kombinovanje, mnogo ređe doslovno kopiranje, kao i zadržavanje nekih karakteristika tradicionalnog vizantijskog slikarstva (zlatni oreoli oko glava svetih ličnosti, ispisivanje njihovih imena, naziva biblijskih događaja i crkvenih praznika). Zajedno sa grčko-cincarskim i rusko-ukrajinskim slikarima, kod Srba se javljaju i prvi domaći majstori koji sve do 1760. uglavnom odlaze na školovanje u Kijevo-pečersku lavru a od tada na umetničku Akademiju u Beč.

Mada u odnosu na umetnost kod Hrvata, barokizacija umetnosti kod Srba kasni nekoliko decenija, u njenim prvim zrelim slikarskim ostvarenjima - zidnim slikama u bačkom manastiru Bođani $(1737)^{16}$ i fruškogorskom Krušedolu (1750-1756) ${ }^{17}$ - nema bitnijih stil-

\footnotetext{
10 Anđela HORVAT, Izmedu gotike i baroka. Umjetnost kontinentalnog dijela Hrvatske od 1500. do oko 1700, Zagreb 1975, 199-202, 272, 292-297; ISTA, Barok u Hrvatskoj, Zagreb 1982, 18-29.

11 Биьана СТОШИЋ, Српска уметност 1690-1740, БеограА 2006, 57-58.

12 ИСТА, Западноевопска графика као предложак у српкком сликарству XVIII века, БеограА 1992.

13 Vladimir MARKOVIĆ, Zidno slikarstvo 17. i 18. stoljeća u Dalmaciji, Zagreb 1985, $29-37$.

14 Vanda PAVELIĆ-WEINERT, Vezilačka radionica 17. stoljeća u Zagrebu, Zagreb 1988; Sanja CVETNIĆ, Ikonografija Tridentskog sabora i hrvatska likovna baština, Zagreb, s. a., 115-117.

15 Бивана СТОШИЋ, Западноевропска графика као предложак у српском сликарству ХVIII века.

16 ISTA, Манастир Бођани - The Monastery of Bodani, Нови СаА 2011.

17 Мирослав ТИМОТИЈЕВИЋ, Манастир Крушедол И, Нови СаА 2008.
} 
skih i ikonografskih razlika od istovremenih fresaka Ivana Rangera u Lepoglavi ili Remetama. ${ }^{18}$

Kao nove teme srpske barokne umetnosti, u ovom periodu se javljaju Krunisanje Bogorodice, Bogorodica Bezgrešnog začeća, Bogorodica Ruža koja ne vene, Bogorodica od sedam žalosti ${ }^{19}$, Silazak Svetog Duha sa Presvetom Bogorodicom, Sveti arhandel Mihailo ubija Sotonu i Oplakivanje Hrista sa Marijom Magdalenom. Uz ovu grešnicu i pokajnicu, prikazuju se starozavetne i novozavetne ličnosti kao što su prorok David, apostol Petar, bludni sin, carinik i „pravedni” razbojnik sa krsta. ${ }^{20}$ Takođe, svojom učestalošću posebno privlače pažnju i izdvajaju se dva obličja Hrista Evharistije: kao vinogradara sa mističnim motivom ceđenja grožđa (Životonosna loza ili Životodajni izvor) i kao polunagog čoveka sa pet rana iz kojih teku mlazevi krvi u putir ili bazen (Fons pietatis ili Fons vitae). ${ }^{21}$ Poznata u južnom Tirolu još od 14. veka kao Hristos paćenik (Schmerzenmann), ${ }^{22}$ ova zapadnoevropska tema preko Poljske prodire u ukrajinske i ruske ilustrovane crkvene knjige 17. stoleća, odakle ih srpski slikari preuzimaju i prenose naročito na ikonostase u Banatu (Stajićevo, Parta) kao predstavu Hristos Životonosna loza..$^{23}$ Drugi ikonografski tip Schmerzensmann-a kao izvora hrišćanskog milosrđa, milosti, ljubavi i života potiče iz holandskih i nemačkih grafičkih listova iz 16. i 17. veka. Mada prikazan kako još živ krvari iz svojih pet rana, Hristos na ovim likovnim predstavama ne trpi bolove, zbog čega je smatran predmetom meditacije i uzorom pobožnosti. Srodnost po jedne zidne oltarske slike iz bačkog manastira Bođana (1737) i hilandarskog paraklisa Bogorodičinog pokrova (1740) potvrđuje javljanje ove barokne teme u srpskoj umetnosti prve polovine 18. veka. ${ }^{24}$

Iako prikaza Svete Ane Trojne u srpskoj umetnosti nema, bečki bakrorezac Jakob Schmutzer za pravoslavni manastir Svete Ane kod Velikih Bastaja u Slavoniji 1758..$^{25}$ izrađuje graviru Bogorodice sa stručkom ruža koja stoji na prestolu pokraj svete Ane, upravo u položaju u kakvom se uobičajeno prikazivao mali Hristos kraj Majke Božije sa epitetom Ruža koja ne vene.

Osim portreta, autoportreta, žanr scena, pejzaža, mrtvih priroda i aktova kao sastavnih delova religioznih kompozicija, u neposrednoj vezi sa mestom gde su predstavljene, javljaju se i alegorijsko-amblematske scene poput hrišćanskih i vladarskih vrlina svojstvenih zapadnoevropskom baroku. Izvorno ilustracije amblematskih knjiga jezuitske provenijencije, one u srpsku umetnost dospevaju prvo preko kijevskih (1712) i moskovskih (1718), a potom i neposredno, preko srpskih izdanja štampanih u Beču u moralizatorsko-didaktičke svrhe (Itika i jeropolitika, 1774). Jedna od najranijih ovakvih predstava jeste amblem $\check{Z} d r a l{ }^{26}$ na

\footnotetext{
Sanja CVETNIĆ, Ikonografija Tridentskog sabora, 38-39.

19 Аејан МЕААКОВИЋ, „Барокне теме српске уметности. І Богородица од седам жалости”, Трагом српског барока, Нови СаА 1976, 251-259.

20 Аинко ААВИАОВ, Српска графика ХVIII века, Нови СаА 1978, 287-288, сл. 91.

21 ISTI, „Барокне теме српске уметности. II Представа Христа као Fons Pietatis у српској уметности”, Барок код Срба, Загреб 1988, 218-225.

22 Isto, 219.

23 Аејан МЕААКОВИЋ, „Барокне теме српске уметности. І Представа Христа као Животоносне Аозе у српској уметности", Барок код Срба, Загреб 1988, 207-217.

24 Биьана СТОШИЋ, Српска уметност 1690-1740, Београд 2006; ISTA, Манастир Бодjaнu - The Monastery of Bodani, Нови СаА 2011.

25 Аинко ААВИАОВ, Српска графика, 357-358, сл. 234.

26 Аејан МЕААКОВИЋ, „Представе врлина у српској уметности XVIII века - II Алегоријска преАстава жАраца на архијерејском столу у цркви манастира Крушедома”, Путеви српског барока, БеограА 1971, $137-140$.
} 
arhijerejskom tronu manastira Krušedola (1765), rad slikara Dimitrija Bačevića. ${ }^{27}$ Preuzet iz arsenala barokne simbolografije, budni ždral sa kamenom u kandži podignute noge je alegorija budnosti i predostrožnosti kao Hristovih i arhijerejskih idealnih vrlina. U drugoj polovini 18. veka isti motiv postaje simbolični atribut na knjižnom građanskom portretu i izvodi se u grafičkoj tehnici bakroreza. ${ }^{28}$ Nekoliko godina ranije, na jednom od bakroreza Svečanog pozdrava Mojseju Putniku Jakova Orfelina (1757), javlja se amblem baroknog srca kao središnji deo stihovanog lavirinta, $s$ ciljem da vatrom pobožnosti i ljubavi prema Bogu podseti na Hristovu žrtvu - davanje sopstvenog srca. ${ }^{29}$

U ovom periodu su rasprostranjene kako starozavetne scene sa simboličnom tematikom tako i Hristove propovedi i parabole ili Devet blaženstava sa moralizatorskim pozivanjem vernika na aktivnu pobožnost. ${ }^{30}$ Ako su jevanđeljske kompozicije tipa Isterivanje trgovaca iz hrama ili Povratak bludnog sina bile u službi snaženja hrišćanske vere, scene kao što su Žrtva Avramova, Kit izbacuje Jonu, Danilo među lavovima ili Vaznesenje svetog Ilije u srpskoj umetnosti, za razliku od hrvatske, izvlačene su iz konteksta biblijskih konkordanci postajući paradigme ljubavi prema Bogu koja čudom sve pobeđuje. Imajući u vidu predstavu Boga Oca sa Devet anđeoskih činova okružene četvoricom jevanđelista i njihovim simbolima u okviru scene na svodu naosa crkve manastira Bođana, ne može se sa sigurnošću tvrditi da u srpskoj umetnosti nije bilo kriptokatoličkih alegorijskih tema tipa četiri elementa, kontinenta ili strana sveta. S druge strane, potvrđujući slikom propoved, naročito nedeljom, parabole su pozivale vernike na smirenost i skromnost (Udovičina lepta), upućivale na pokajanje, ispovest i vraćanje pod okrilje crkve (Bludni sin), osuđivale licemerje (Trun i brvno u oku) i podsećale da su putevi sagrešenja i iskupljenja dijametralno suprotstavljeni (Milostivi Samarićanin).

Izdvojeni ikonografski segment predstavljaju Bogorodica Carica Krilata ${ }^{31}$ kao odraz zapadnjačkog kulta Schutzmantel Madonne, velike zaštitnice monaških redova, i serijski izrađivana čudotvorna ikona Crne Bogorodice Egipatske, Arapske ili Saracenske čije se poštovanje kao zaštitnice lekovitih izvora i podzemnih voda ne iscrpljuje 18. stolećem nego se produžava do u 20. vek. Nove ikonografske teme srpskog baroka pojavljuju se gotovo istovremeno u zidnom slikarstvu (tehniku al fresco odmenjuje prvo al secco, a kasnije i ulje na malteru), u grafici i u ikonopisu, zajedno sa odjecima u minijaturnom slikarstvu (Gavril Stefanović Venclović). Zanimljivo je da se zaštita koju krilata Carica neba pruža svojim Pokrovom od vidljivih i nevidljivih neprijatelja, kao i Bogorodica Bezgrešnog začeća i Bogorodica Ruža koja ne vene, dovode u neposrednu vezu sa odbranom pravoslavnih hrišćana od turskog vojnog prisustva i daljih osvajanja. I ponavljanje većeg broja predstava sa Svetom Trojicom kao Troglavim Hristom i Svetog Hristofora sa pasjom glavom korespondira sa reakcijom istočnohrišćanske crkve na viševekovno ropstvo pod Turcima, odnosno, pozivom na versku homogenizaciju. Odgovarajuće paralele mogu se povući sa istovremenim jezuitskim tipom Marije Snježne Petrovaradinske poznate i kao Marija Pomoćnica ili Gospa od Sniga. ${ }^{32}$

\footnotetext{
Мирослава КОСТИЋ, „САикани програм тронова”, Тронови ирквеманастира Крушедола, Нови СаА 2009, 97-133.

28 Аинко ААВИАОВ, Сриска графика, ХІІ.

29 Јемена ТОАОРОВИЋ, Ентитет у сенщи. Мапирање моћи и државни спектакл у Карловачкој Митрополији, Нови СаА 2010, 86-98.

30 Мирослав ТИМОТИЈЕВИЋ, Српско барокно сликарство, Нови СаА 1996, 415.

31 Мирјана ТАТИЋ ЂУРИЋ, „ЈеАна нова тема словенског барока”, Западноевропски барок и византијски свет. Зборникрадова (ур. Аејан Медаковић), БеограА 1991, 123-136.

32 Sanja CVETNIĆ, Ikonografija Tridentskog sabora, 76-77.
} 
Ove se pravoslavne freske i ikone po svojem učestalom predstavljanju u odbrambene svrhe mogu u umetnosti u katoličkom svetu, pa i kod Hrvata, porediti jedino sa kipovima Presvetoga Trojstva, Bezgrešnoga začeća ili nekog lokalnog svetitelja iznošenih sa crkvenih oltara na gradske stubove ili na raskršća seoskih puteva, gde postaju javni verski spomenici postavljani u znak zahvalnosti za prestanak epidemije kuge. ${ }^{33}$

Sklonost epohe baroka ka nakaznom i bizarnom našla je odjeka u predstavama istočnopravoslavne i srpske umetnosti kao što su troglava Sveta Trojica (Trimurti), ${ }^{34}$ Bogorodica Trojeručica i Sveti Hristofor Kinokefa ${ }^{5}$. Posebnu osobenost ovog fenomena predstavlja njihova pojava na rubnim područjima crkvene arhidijeceze čije je izvođenje bilo delo ruku malih lokalnih majstora ili putujućih zografa. Njihov uporni opstanak rezultira radijalnim širenjem i prodorom u glavne crkvene centre (Hilandar, Pećka patrijaršija, Sremski Karlovci). Isprva tolerisani, folklorni elementi ove popularne umetnosti na kraju potpadaju pod izričitu zabranu ukaza propisivanih sa najvišeg crkvenog mesta, uz upućivanje na radove rusko-ukrajinskih školovanih umetnika po priznatim likovnim priručnicima - grafičkim predlošcima i slikarskim erminijama. Ipak, uprkos zabranama ili upravo zahvaljujući otporu crkvenim autoritetima, i na Zapadu i na Istoku ovakve neobične i nedolične predstave su uglavnom privremenim uklanjanjem preživele sve do naših dana. Kao pandan zabranama Tridentskog sabora (1563) i papskih bula Urbana VIII i Benedikta XIV u 17. veku, ruski Sveti Sinod u vreme Petra I Velikog višekratno proglašava bogohulnim impozantni broj kanonskih i nekanonskih izopačenosti na granici između protestantizma i rimokatolicizma.

Tanku granicu i male suštinske razlike između crkvenih slika različitih veroispovesti potvrdiće u drugoj polovini 18. veka i podjednako uspešno angažovanje domaćih i inostranih akademski obrazovanih umetnika i za pravoslavnu i za rimokatoličku klijentelu (Teodor Ilić Češljar, bečki grafički atelje porodice Schmutzer).

Heteregenost i eklektičnost umetnosti i umetnika kod Srba i Hrvata u XVIII veku ne odstupa od sličnih suštinskih karakteristika srednjoevropskih stilova ovoga razdoblja, baroka i rokokoa. Afektiranost i prenaglašena retoričnost bile su sveprisutne, a ispoljavale su se kroz telesnu tordiranost (tzv. zmijolika linija), gestikulaciju ruku i patetični izraz lica kao preporučena, katkada i slikovna uputstva za dosezanje uverljivosti crkvene propovedi. Njihov krajnji cilj bilo je postizanje uživljavanja vernika u hrišćansku dramu sve do katarzično-preobražajnog izmamljivanja suza i plača. U srpskoj umetnosti zavisnoj od zapadnoevropskih grafičkih predložaka, prvo će u grafici a onda i u monumentalnom i minijaturnom slikarstvu doći do sve uočljivijeg prisustva anđela i arhanđela kao moralizatorskih posrednika između Boga i ogrehovljenih ljudi (Anđeo čuvari ili Hranitelj duševni), ujedno i glavnih nosilaca „nemih propovedi”. Tako će ovaj vek ostati upamćen po preplitanju slike i reči u tolikoj meri da je govor postajao slikovit a slika počinjala da govori.

Prvo terezijanske a potom i jozefinističke reforme sprovođene iz Beča između 1769. i 1790. godine, postepeno su otupljivale oštrice militantne rimokatoličke crkve, utirući put verskoj toleranciji i umetnosti lišenoj naglašenog konfesionalnog identiteta. Kako je dobro zapazio Leonid Uspenski, pravoslavno učenje u pokušaju paralelnog ili dvojnog negiranja zadobija „kompeks niže vrednosti” od kojeg se dugo neće osloboditi: u suprostavljanju ri-

\footnotetext{
33 Isto, 211-216.

34 Ljiljana STOŠIĆ, „Icône de Sainte Trinité du Musée de l’Église orthodoxe serbe. Le Crist Trimurti”, Serbie, terre sacrée de la culture européene. Catologue de exposition (27 mars au 2 mai 2010), Chapelle des Mineurs de Faymoreau, Vendée /France/, 6, 46-47.

35 ISTA, „Култ светог Христофора Кинокефала на Балкану”, PATRIMONIUM.MK, 2010, 6р. 7-8, 393-401.
} 
mokatolicizmu, ono pribegava protestantskim argumentima i obrnuto, u borbi protiv protestantizma, preuzima izvorne rimokatoličke dogmate. ${ }^{36}$

Reči Davida Freedberga izrečene pre više od dve decenije o velikom zadatku istorije umetosti da pronalazi originale i prati svu raskoš njihovih neočekivanih razrada i preobražaja u kopijama, dobijaju na snazi već ovlašnim uvidom u sličnosti i razlike u umetnosti kod Srba i Hrvata u Habsburškoj Monarhiji. Ne treba smetnuti s uma da se usredsređenošću na pronalaženje razlika često ispušta iz vida obrnuti proces - prepoznavanje suštinskih sličnosti - tim pre što su one često samo formalno prerušene da bi se na prvi pogled učinile drugačijima.

Postbarokni umetnički procesi i estetske kategorije ne samo da su prisutni nego su i vladajući u savremenom svetu neobarokne kulture postmoderne (fotografija, film, video i digitalna umetnost). Svekolika žudnja modernog čoveka za pokretom, raznovrsnošću, neprekidnim promenama, kao i uživanja u novom, originalnom, stranom i nebičnom, samo su derivati procesa barokizacije, evropeizacije i modernizacije koji su u 18. veku zahvatili rubna područja Habzburške Monarhije na kojima su živeli Srbi i Hrvati. Upoznavanje sa autentičnim osobenostima njihove kulture i umetnosti danas se više nego ikada čini neophodnim kako bi se spremnije uhvatilo u koštac sa novim svetskim izazovima, uz više svesti i razumevanja za zajedničku tradiciju dugu više od tri stoleća.

\section{Baroquization of Art among the Serbs and the CROATS UNTIL I760 SIMILARITIES AND DIFFERENCES}

The heterogeneity and eclecticism of the art and artists among the Serbs and the Croats in the first half of the $18^{\text {th }}$ century were not significantly different from the corresponding features of the styles current in Central Europe at that time - Baroque and Rococo. The pervasive affectation and exaggerated rhetoricism were embodied in undulating forms of human bodies, vigorous gesticulation and pathetic facial expressions, which reflect the recommended visual manuals (sometimes printed) for achieving persuasiveness in religious sermons. Their ultimate purpose was to entice transformative tears and weeping from believers. In Serbian art, which largely drew on Western European copperplate pattern books, the effects of the processes of Baroquization, Europeanization or modernization could first be observed in graphic art and architecture and only later in mural (frescoes), easel (icons) and miniature (book illumination) painting and applied art, whereas in Croatian art, these processes run simultaneously in all arts. The main characteristics of the mid$18^{\text {th }}$-century Serbian and Croatian art is the intertwining of words and images to such an extent that narration became pictorial and images became narrative. Owing to the reforms carried out under Empress Maria Theresa and her son, Emperor Joseph II, the militant propaganda of the Roman Catholic Church gradually abated. These reforms paved the way to religious tolerance and an art independent of confessional affiliation. Seeking differences in the art of neighbouring peoples often leads to failure to see fundamental similarities disguised with the intention to merely look different. The purpose of this study is to draw attention to some of them.

Keywords: Emblematics, Baroque, Copperplate pattern books, Habsburg Empire, Modernization, Serbian and Croatian Art, Western European illustrated Bibles

36 АеониА УСПЕНСКИ, Теологија иконе, Манастир Хиландар 2000, 261. 


\section{$\cos$}

\section{Literatura:}

Slobodan ANTONIĆ, „Modernizacija”, Kritički pojmovnik civilnog društva (I), Beograd 2003.

John BOURKE, Baroque Churches of Central Europe, London 1978.

Sanja CVETNIĆ, Ikonografija nakon Tridentskog sabora i hrvatska likovna baština, Zagreb (s. a.).

Аинко ААВИАОВ, Српска графика ХVIII века, Нови СаА 1978.

Вим и Ариел АЈУРАНТ, Аоба Волтера. Историја щивилизачије Западне Европе од 1715. до 1756, са посебним нагласком на сукоб између религије и филозофије, БеограА $2004^{2}$.

Elfriede IBY, Maria Teresa (1717-1780). Biografia de una soberana, Wien 2010.

Anđela HORVAT, Izmedu gotike i baroka. Umjetnost kontinentalnog dijela Hrvatske od oko 1500. do oko 1700., Zagreb 1975.

ISTA, Barok u Hrvatskoj, Zagreb 1982.

Александар КААИЈЕВИЋ, Архитектура и дух времена, Београд 2010.

Мидраг КОААРИЋ, „Модернизација српског сликарства у раздобьу зографа и молера”, Зборник Матище сриске (Серија Аруштвених наука), 1954, бр. 8, 87-98.

Бранка КУАИЋ, Новосадске дрворезбарске радионище у 18. веку, Нови СаА 2007.

Vladimir MARKOVIĆ, Zidno slikarstvo 17. i 18. stoljeća u Dalmaciji, Zagreb 1985.

Аејан МЕААКОВИЋ, Путеви српског барока, Београд 1971.

ИСТИ, Трагом сриског барока, Нови СаА 1976.

ИСТИ, Сриска уметност у ХVIII веку, БеограА 1980.

ИСТИ, Барок код Срба, Загреб 1988.

Vanda PAVELIĆ-WEINERT, Vezilačka radionica 17. stoljeća u Zagrebu, Zagreb 1988.

Мирјана А. СТЕФАНОВИЋ, Аексикон сриског просветитељства, БеограА 2009.

ьиьана СТОШИЋ, Западноевропска графика као предложак у српском сликарству ХVIII века, Београд 1992.

ИСТА, Сриска уметност 1690-1740, Београд 2006.

ИСТА, „Icône de la Sainte Trinité du Musée de l'Église orthodoxe serbe: Le Christ Trimurti”, Serbie, terre sacrée de la culture européene, Catalogue de exposition du 27 mars au 2 mai 2010, Chapelle des Mineurs de Faymoreau, Vendée /France/.

ИСТА, „Култ светог Христофора Кинокефама на Бамкану”, PATRIMONIUM.MK, 2010, бр. 7-8, 393-404.

ИСТА, Манастир Бођани - The Monastery of Bodani, Novi Sad 2011.

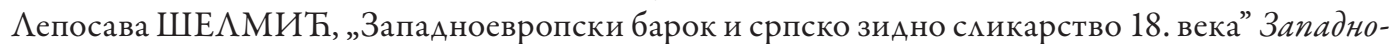
европски барок и византијски свет. Зборник радова (ур. Аејан Медаковић), БеограА 1991.

Мирјана ТАТИЋ ЂУРИЋ, „ЈеАна нова тема словенског барока”, Западноевропски барок и византијски свет. Зборник радова (ур. Аејан Медаковић), БеограА 1991.

Мирослав ТИМОТИЈЕВИЋ, Сриско барокно сликарство, Нови СаА 1996.

ИСТИ, Манастир Крушедол, I-II, Нови СаА 2008.

Мирослав ТИМОТИЈЕВИЋ, Бранка КУАИЋ, Роберто САКУМАН, Мирослава КОСТИЋ, Аанијела КОРОАИЈА ЦРКВЕНАКОВ, Тронови чркве манастира Крушедола, Нови СаА 2009.

Јемена ТОАОРОВИЋ, Ентитет у сенци. Мапирање моћи и државни спектакл у Карловачкој митрополији, Нови СаА 2010.

Leonid USPENSKI, Teologija ikone, Manastir Hilandar 2000. 


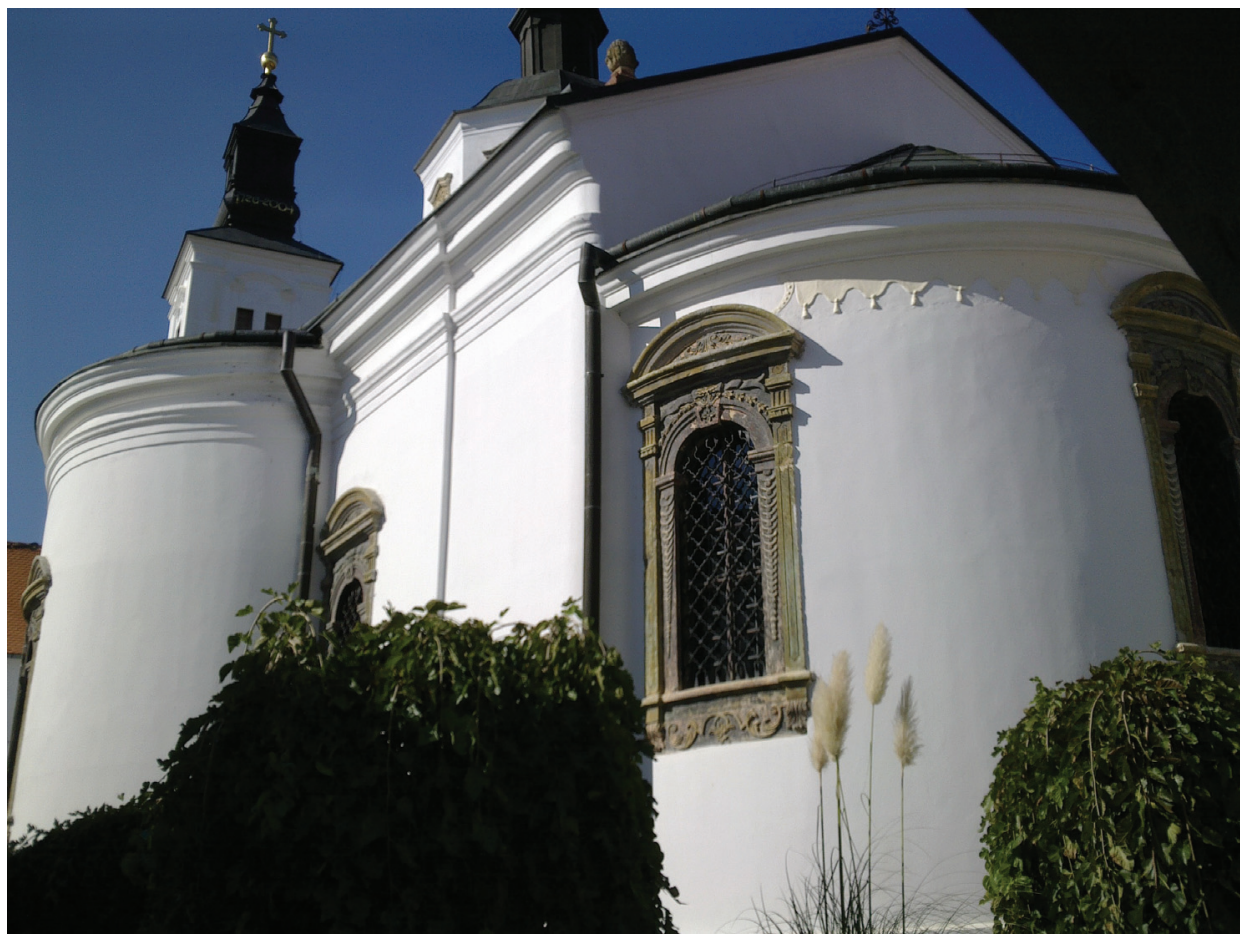

1. Crkva manastira Krušedola, pogled sa jugoistoka (1722-1745)

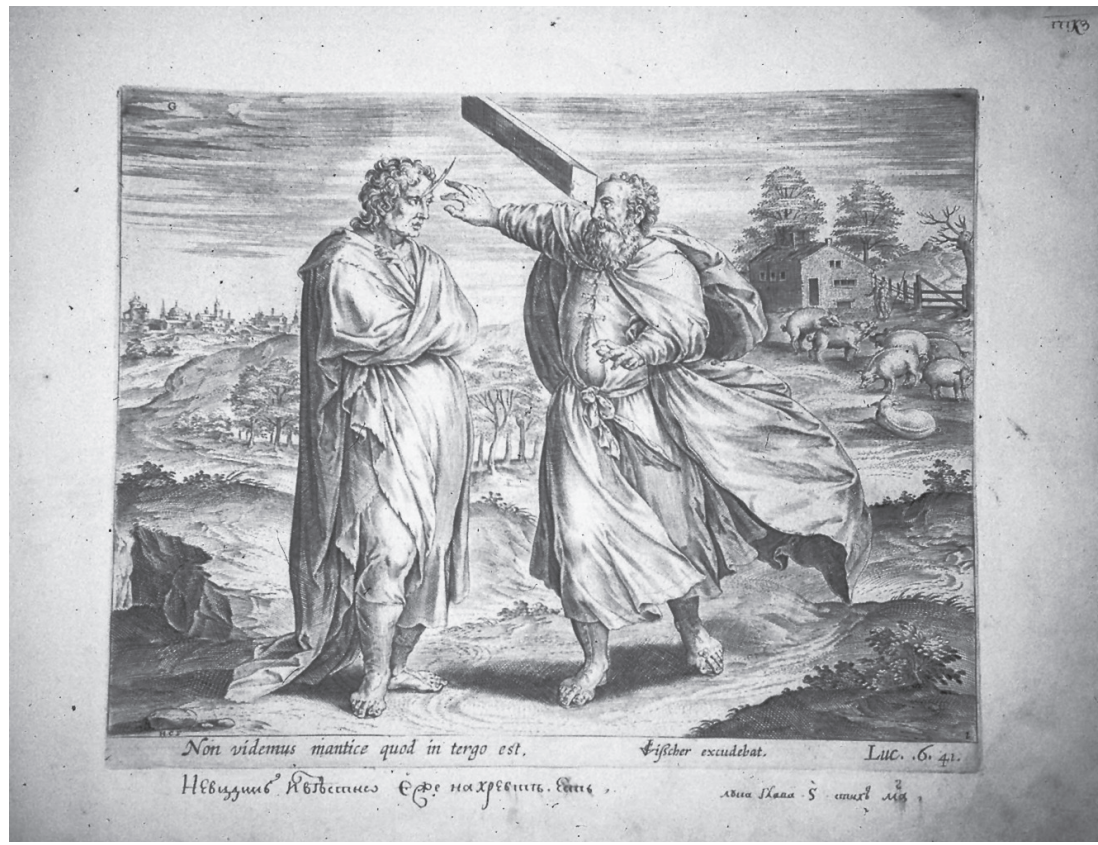

2. N. J. Visscher zvani Piscator, Parabola o trunu i brvnu u oku, bakrorez (XVI vek) 


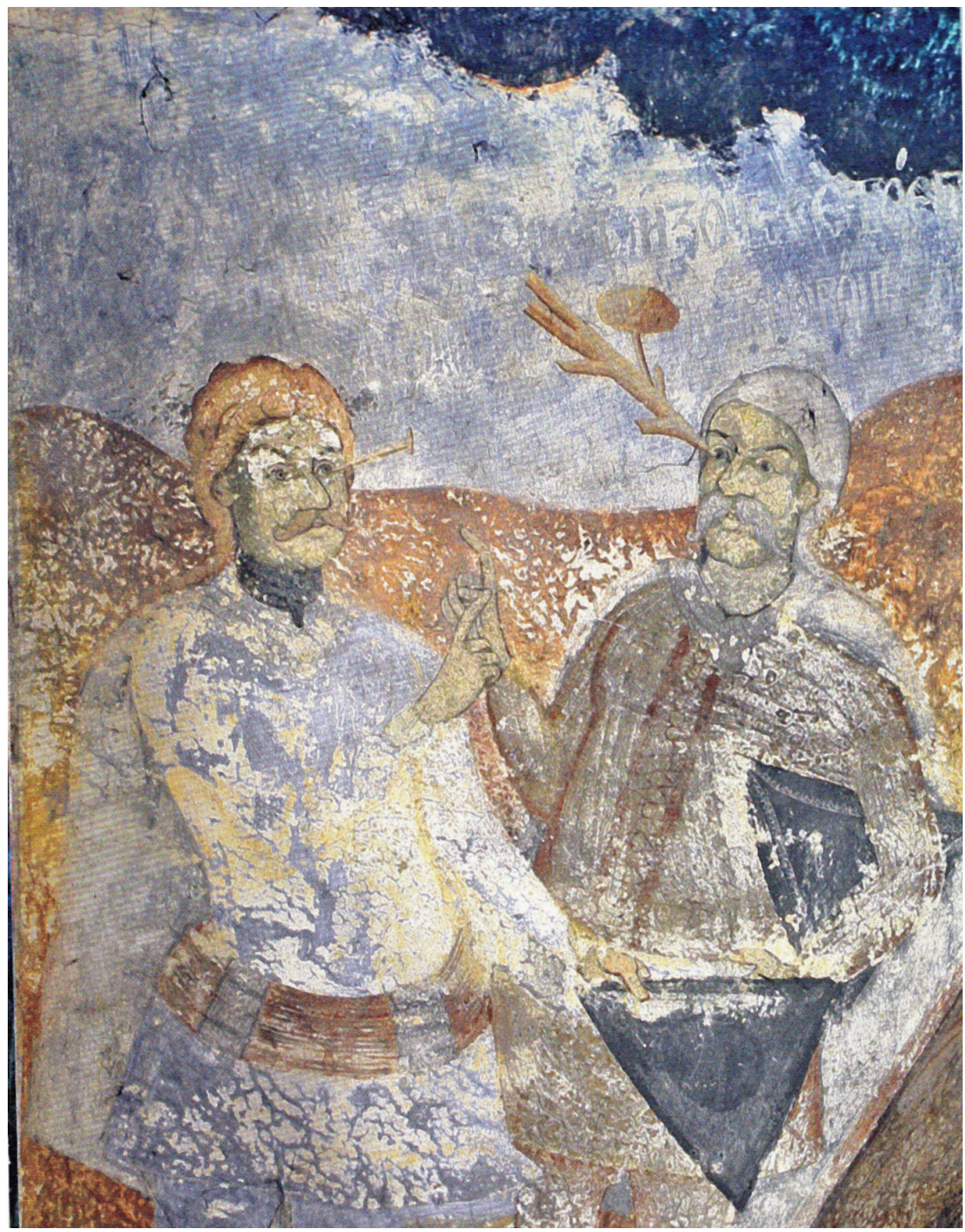

3. H. Žefarović, Parabola o trunu i brvnu u oku, zidna slika, crkva manastira Bođana (1737) 


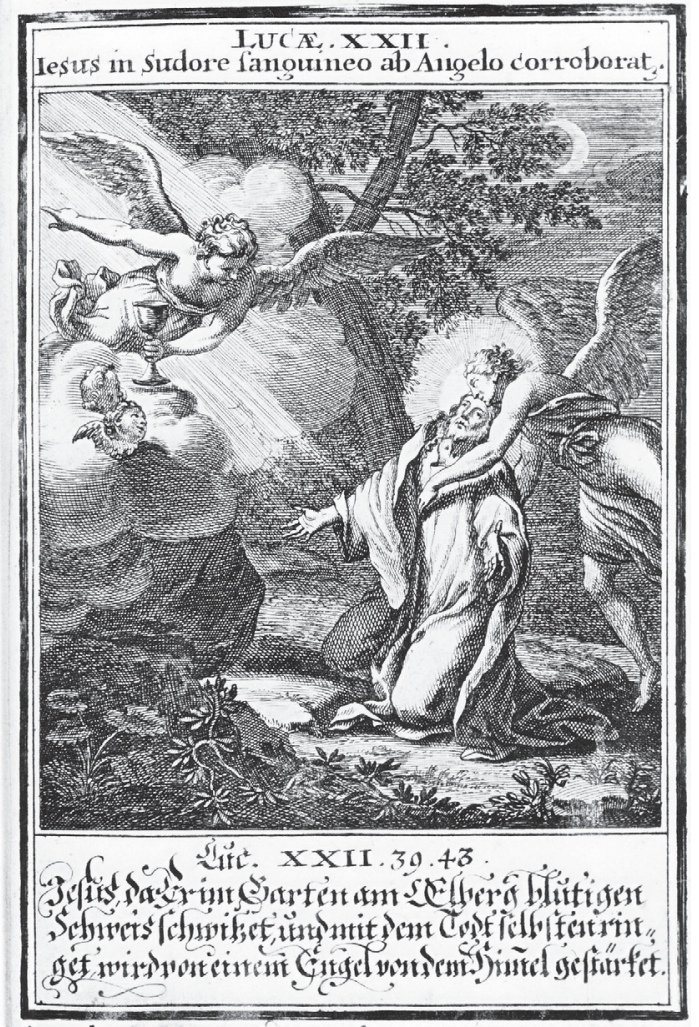

4. C. Weigel, Molitva u Getsimanskom vrtu, bakrorez (1695)

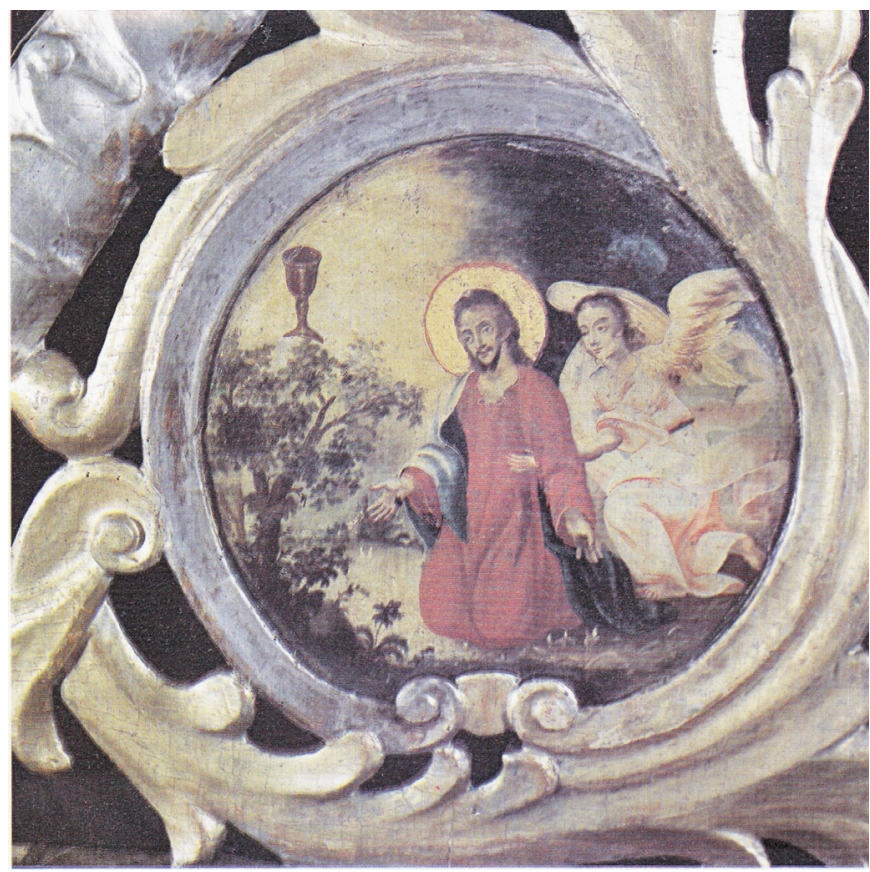

5. N. Nešković, Molitva u Getsimanskom vrtu, ikonostas crkve Sv. Georgija u Temišvaru (1764) 


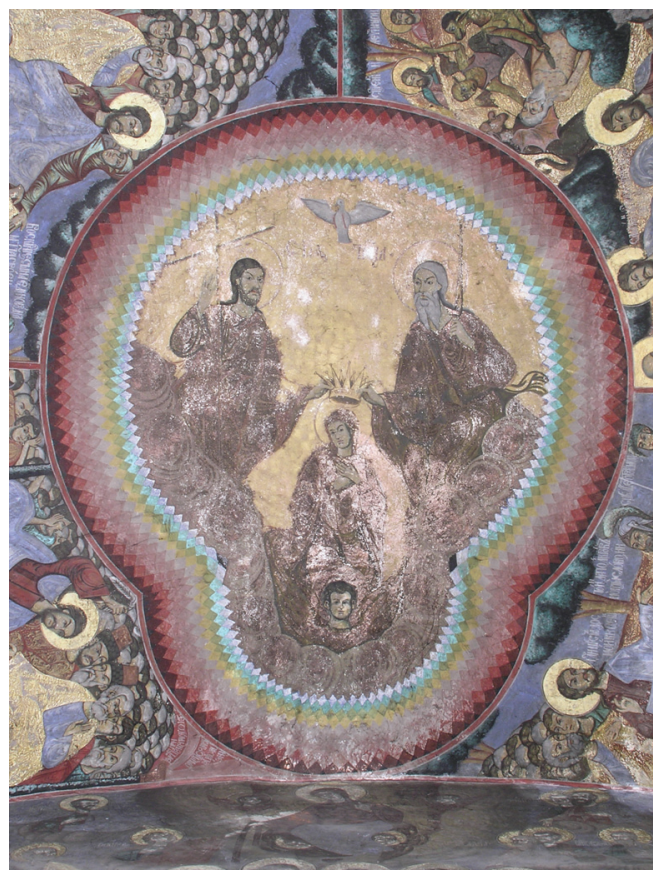

6. H. Žefarović, Krunisanje Bogorodice, zidna slika, crkva manastira Bođana (1737)

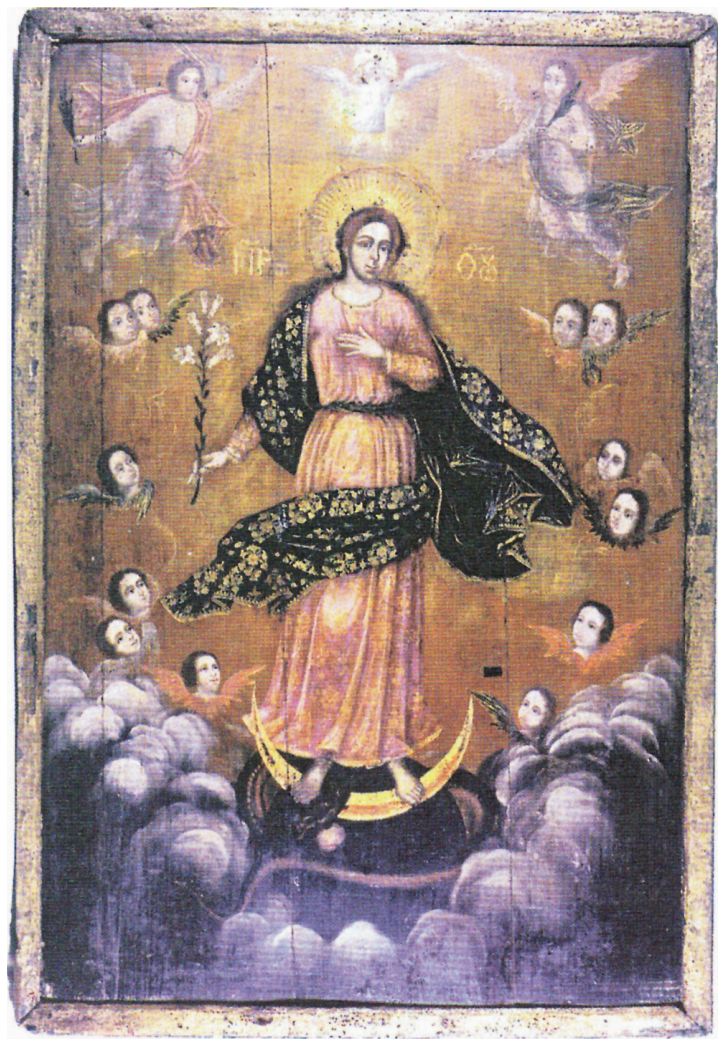

7. J. Halkozović, Bogorodica Bezgrešnog začeća, crkva Sv. Arhanđela, Sarajevo (oko 1760) 


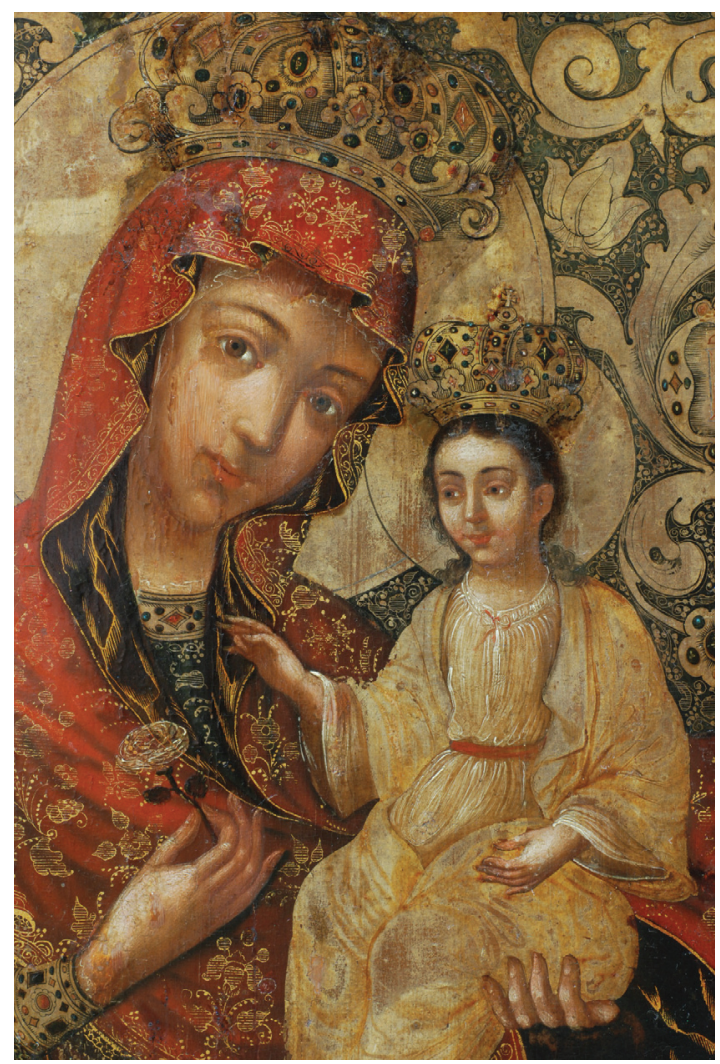

8. J. Vasilijevič, Bogorodica Ruža koja ne vene, ikona iz manastira Bođana (1742)

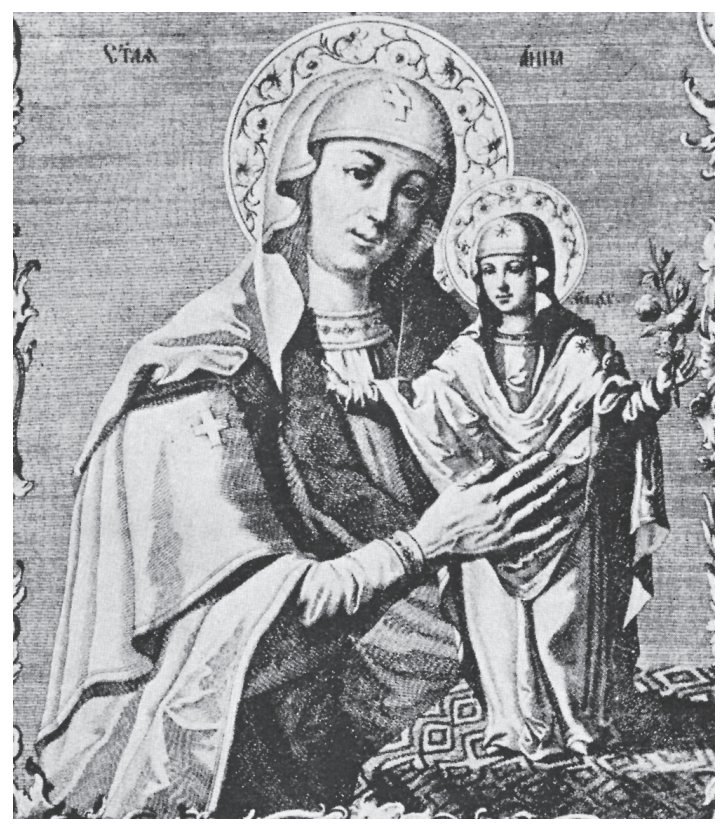

9. J. Schmuzer, Sveta Ana sa Bogorodicom, bakrorez sa vedutom manastira Sv. Ane kod Velikih Bastaja, Daruvar (1758) 


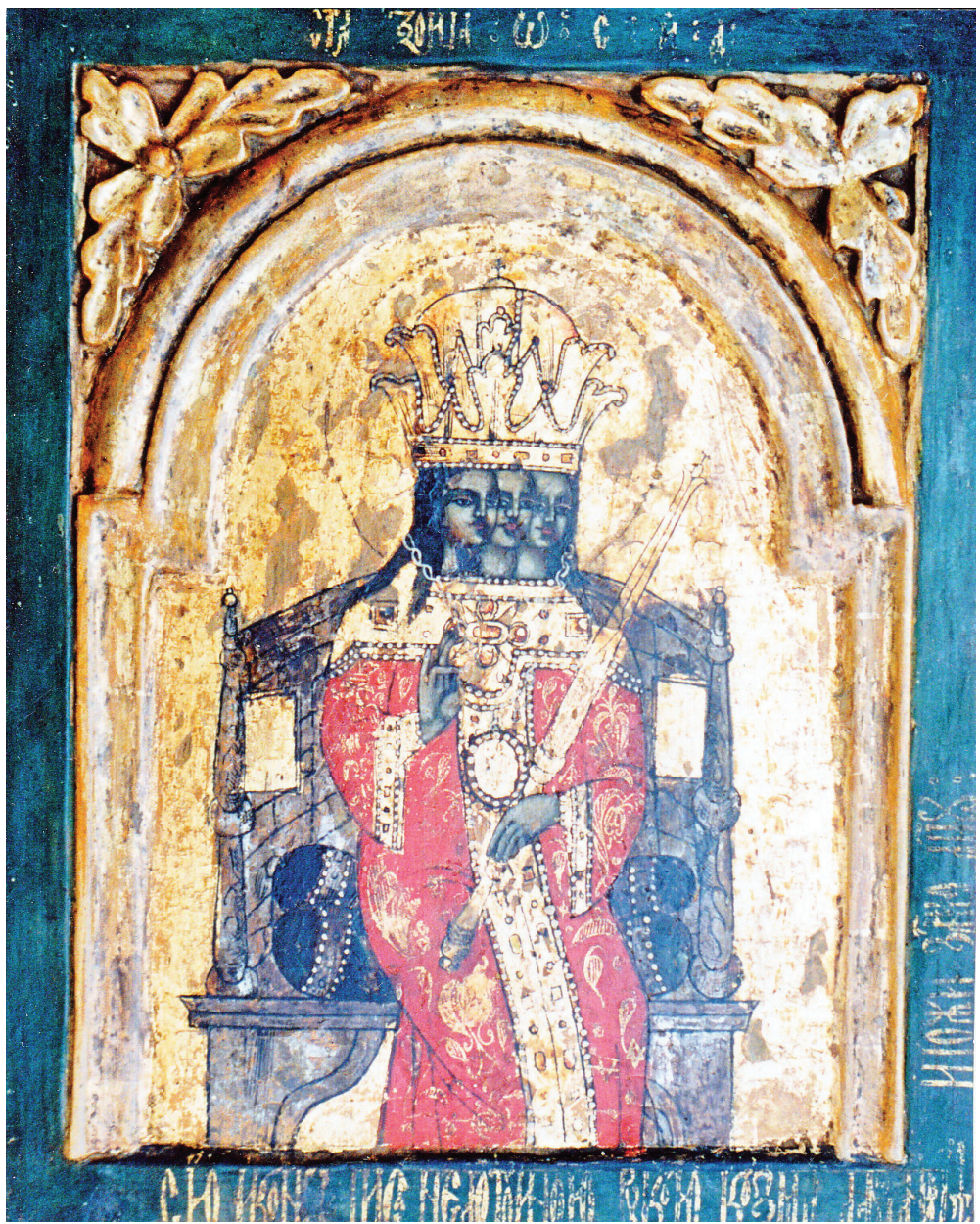

10. Kuzma Damjanović, Sveta Trojica, ikona u crkvi u Poveliću kod Križevaca (1704) 